\title{
Water Supply and Demand Status of Areka Town, Southern Ethiopia
}

\author{
Wondimu Elias Worajo \\ Lecturer, Wolaita Sodo University, Department of Hydraulic \& Water Resources Engineering, 138 \\ Tadewos Adema Amona \\ Lecturer, Wolaita Sodo University, Department of Hydraulic \& Water Resources Engineering, 138
}

\begin{abstract}
Water is one of the vital necessity or the need for human being and for all living things. This study was conducted to assess the existing and to forecast the future water supply and demand status of the Areka town, southern Ethiopia. A total of 196 households (HHs) were randomly selected and interviewed by using a questionnaire. To collect the required data, interview and observation were used and written documents were reviewed. Data analyzed by SPSS and Excel spread sheet. The town population was growing rapidly, but water production was low, i.e. only $720 \mathrm{~m}^{3} / \mathrm{d}$. This covers only $51.9 \%$ of the total population. Additional water production of $26.49 \mathrm{l} / \mathrm{s}$ $\left(2288.7 \mathrm{~m}^{3} / \mathrm{d}\right)$ was required to fill the gap. Available per capita water demand, i.e. $11.481 / \mathrm{c} / \mathrm{d}$ was small as compared to WHO basic access standard, i.e. $20 \mathrm{l} / \mathrm{c} / \mathrm{d}$. The total revenue water and non-revenue water from the existing water production were $525.18 \mathrm{~m}^{3} / \mathrm{d}$ and $194.81 \mathrm{~m}^{3} / \mathrm{d}$, respectively. About $48 \%$ of $\mathrm{HHs}$ got their primary water from existing water supply lines and the remaining 52\% got their primary water from non-connected sources. In order to narrow the supply and demand gap, expansion of water supply services and additional water sources should be provided.
\end{abstract}

Keywords: Water supply, water demand, supply coverage, water production, Areka Town, Ethiopia

DOI: $10.7176 / \mathrm{JRDM} / 77-02$

Publication date:July $31^{\text {st }} 2021$

\section{INTRODUCTION}

Water is one of the vital necessity or the need for human being and for all living things (Temesgen M., 2018). Many countries in both the developed and developing world face significant problems in maintaining reliable water supplies and this is expected to continue in future years due in part to the impacts of global climate change. Growing populations will further increase the demand for water, with limited cost-effective water supply augmentation options (Dharmaratna D, Harris E , 2010). The access of enhanced clean water supply is one of the major factors that greatly contribute to the socio-economic transfer of country by improving the life style and health, thereby escalating life standard and economic productivity of the society (Bogale, 2016). In the world fresh water that has been used for household $(\mathrm{HH})$ purpose is not $>3 \%$ of the natural available water resource on the earth (WHO/UNICEF, 2017). This is very small in amount of wholesome water, compared with the saline water body exists on earth. As a result, millions of people in the world are facing a shortage of adequate safe drinking water (DW) in terms of quantity and quality. The provision of adequate supplies of potable water for use in urban areas in developing countries is crucial for the well-being of the people. The demand for such supplies in the developing countries has been increased over time as a result of rising standards of living that occur with economic progress and population increase resulting from natural growth, and rural urban migration and rising per capita income (Rewata J, Sampath R, 2000).

The majority of the developing countries in Africa and Asia are greatly affected by the problems of access to clean and safe potable DW supply (UN, 2012). However, most of the developing countries like Ethiopia still unable to obtain adequate potable water and have low potable DW supply coverage. Ethiopia is very well- known by its massive water resource potential all of which is generated in its own and it is still known as the water tower of Africa (Makonnen A, 2014). But, access of potable DW supply coverage in Ethiopia is amongst the lowest in sub-Saharan Africa (SSA), as well as the entire world (57.3\% in 2015). Currently, majority of the existing Ethiopian urban water supply and sanitation system designs are absolute but the rate of rehabilitation and expansion has been lagging behind. Estimates revealed that about $52 \%$ of the population in Ethiopia traveled half an hour or more to collect water every day (CSA, 2007). This long travel distance to the nearest water source directly affects women and children who are mainly responsible for fetching water. It is difficult for most girls and children to attend and succeed in school since a considerable amount of their time is used for domestic chores, including fetching water. This has an implication on the productivity of women. According to the UN-Water, in 2017 only $11 \%$ of the population used a safely managed DW service on their premises. Another $30 \%$ used a "basic service" ( $<30$ min round trip for water collection), with the remainder having to rely on "limited service" $(>30$ min), "unimproved sources" (e.g. unprotected dug wells or springs) or surface water. Only $7 \%$ of the population used a safely managed sanitation service, $7 \%$ only had "limited service" (latrines shared with other HHs), 63\% had 
to rely on "unimproved service" (e.g. a simple pit or a bucket) and $22 \%$ defecate in the open (https://en.wikipedia.org/wiki/Water_supply_and_sanitation_in_Ethiopia\#Access).

In Ethiopia, all sources confirm that water supply coverage is on a strong upward trajectory. According to official government data, water supply coverage has risen from $19 \%$ in 1990 (11\% rural, $70 \%$ urban) to $66 \%$ in 2009 (62\% rural, 89\% urban) (UNICEF, 2011). According to the report of Ministry of Health and Ministry of Water and Energy, access to safe DW increased from $23.1 \%$ in 1998 to $68.5 \%$ in 2012 . However, millions of people in urban and rural areas have not been getting safe DW from an improved water source. In the case of Southern Nation Nationalities and Peoples' Regional State (SNNPRS), clean water supply access in terms of coverage reached $53.9 \%$. Major problems of water supply in urban centers of Ethiopia include low production levels, inadequate distribution systems and leakages in many areas (Mandefro C, Habtamu K, 2017).

This study conducted in one of the small developing towns in Ethiopia, viz. Areka town, Southern Ethiopia, in which there is a growing demand for water and sanitation services due to growing populations, rising standards of living and per capita incomes. However, the demand for water in the town is growing much faster than the supply. The cause for this problem is that the existing water supply systems in the towns are not performing as intended by its design.

\section{OBJECTIVE OF THE STUDY}

The main aim of this study was to assess the existing and to forecast the future water supply and demand status or scenario of the Areka town.

\section{Specific Objectives}

1. To evaluate the functionality and service level of the existing water supply system in the town,

2. To evaluate the source type, status and coverage of water supply in the area,

3. To evaluate the water production and consumption of the town

4. To forecast future water demand scenario in the area

\section{MATERIALS AND METHODS}

\section{Study area description}

Areka is a town in southern part of Ethiopia. It is located in the Wolayita Zone of the Southern Nations, Nationalities, and Peoples' Region some $300 \mathrm{~km}$ southwest of the capital Addis Ababa. This town has a latitude and longitude of $7^{\circ} 4^{\prime} \mathrm{N} 37^{\circ} 42^{\prime} \mathrm{E}$ and an elevation of $1,774 \mathrm{~m}$ above sea level. It is the administrative center of Boloso Sore Woreda. Areka is served by a sub-office of the Ethiopian postal service. The town was founded in 1959, and a primary school opened in the town in 1962. The Ethiopian Institute of Agricultural Research opened a center in Areka in 1985 dedicated to improving the yield of enset. Based on figures from the Central Statistical Agency in 2007, this town has an estimated total population of 31,408 (15,795 men and 15,613 women). The 1994 national census reported this town had a total population of 12,294 (5,970 males and 6,324 females). Areka features a Tropical Savanna Climate with an average rainfall reaches 1,290 mm (https://en.wikipedia.org/wiki/Areka). 


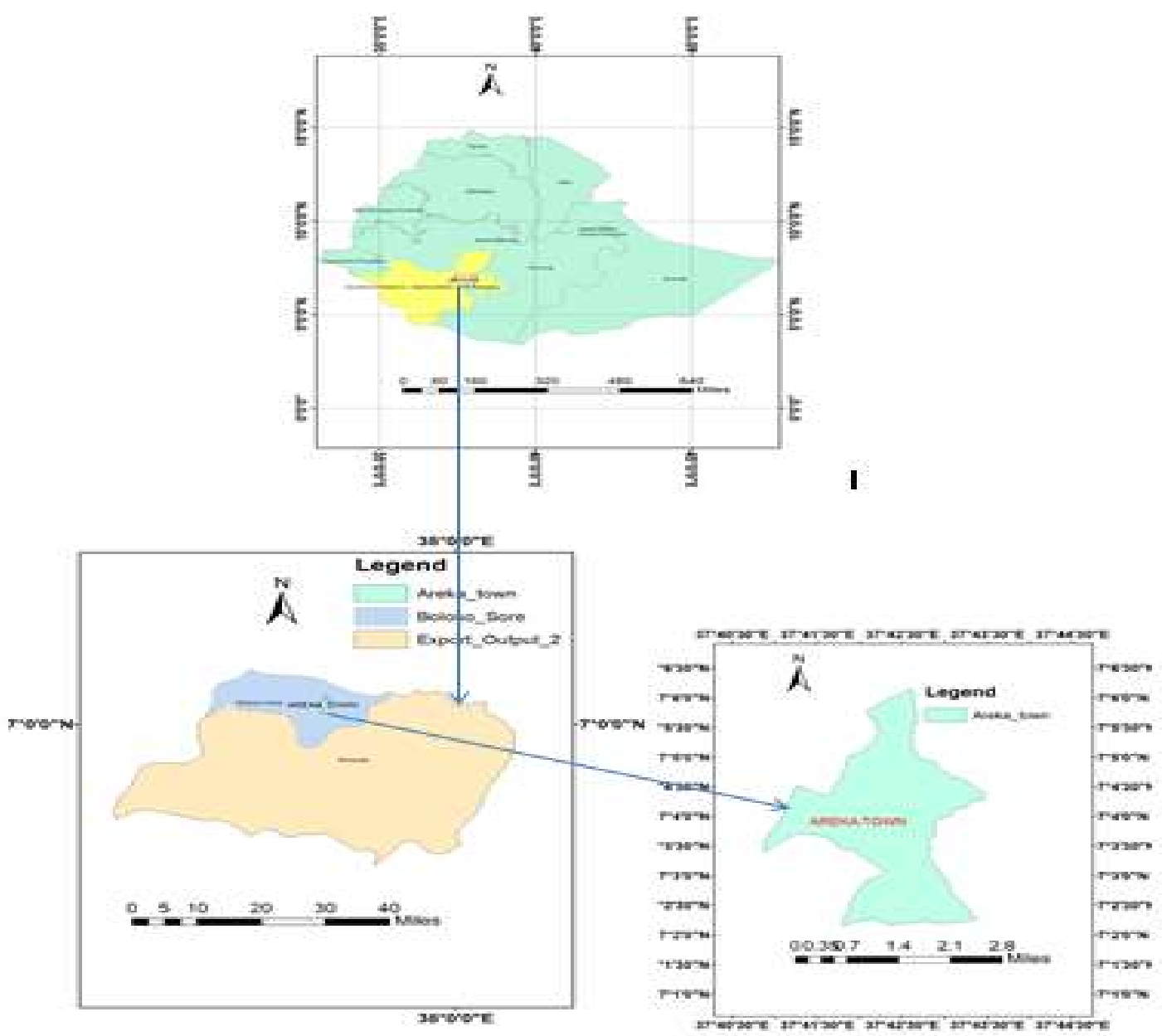

Figure 1: Locational map of study area

Data and data collection method

The survey (quantitative and qualitative methods) is designed to explain concepts and measures to demonstrate implications of the issue under question. Primary data was collected from respondents using questionnaires and the personal field observations were employed to supplement respondents' response. Structured and semistructured questionnaire were prepared for the survey. The questionnaire included an introductory part, questions on the characteristics/attributes of the respondents, water sources and accessibility, potable water coverage and water supply satisfaction. Secondary data (i.e. existing water supply status like source potential, system input volume, design parameters, existing modes of services, etc.) were collected from design documents and related literature.

\section{Sample size, sampling method and data analysis}

In order to determine the sample size that represents the population, a mathematical formula suggested by (Fink A, Kosecoff J, 1995) was employed as presented:

$N=\frac{Z^{2} p q}{d^{2}}=\frac{(1.96)^{2} * 0.519 * 0.481}{(0.07)^{2}}=196$

Where $\mathrm{N}=$ Sample size, $\mathrm{Z}=95 \%$ confidence level corresponds to the value $1.96, \mathrm{p}=0.519$ (water supply coverage of the town), $\mathrm{q}=1-\mathrm{p}$ and $\mathrm{d}=$ proportion of sampling error tolerated at 0.07 . Therefore, 196 samples $\mathrm{HHs}$ were selected from a total of $27,508 \mathrm{HHs}$ of the town.. The field data collection consisting of interviews of the selected sample HHs from 3 sub cities (viz. Arada, Mehal and Sefere Selam); to collect the questionnaire based data from the end- users of the towns' water supply service, a systematic and purposive sampling technique were applied. In each sub cities, the criteria like socio- economic growth (i.e. high, medium and low ), the areas with different conditions of the water supply service (i.e. with access and without access) to existing water supply 
service and connection type (House connection, yard- owned connection, yard- shared connection, public tap and others) were applied to select the sample HHs. The computer software applications SPSS (Statistical Package for Social Science) and Micro soft Excel were used to analyze the data.

\section{RESULTS AND DISCUSSIONS}

\section{Water production and consumption}

The town has three sub cities (i.e. Arada, Mehal and Sefere Selam). The total population of the town was 120,560 (i.e. male $=60,514$, female $=60,046$ ). From the total population, only 62,571 people get safe and potable water from the existing water supply (Table 1). This figure shows the water supply coverage is $51.9 \%$. The main source of water for the town is ground water and a spring with a total production capacity of $262,800 \mathrm{~m}^{3} / \mathrm{yr}\left(720 \mathrm{~m}^{3} / \mathrm{day}\right.$; Table 2). The total /capita water in the town was $11.48 \mathrm{~L} /$ capita/day. This result still very low as compared to WHO basic access within $30 \mathrm{~min}$ round trip, i.e. $20 \mathrm{~L} /$ capita/day. The total water demand of the town to be in WHO basic access is $1,253.82 \mathrm{~m}^{3} /$ day. Currently the gap between supply and demand is $533.83 \mathrm{~m}^{3} /$ day. It means within the current water supply coverage of $52 \%$, an additional water source with a total capacity of $533.83 \mathrm{~m}^{3} / \mathrm{day}$ is needed for a served population to be within the WHO water supply basic access.

Table 1: Water Supply coverage

\begin{tabular}{|l|l|l|l|}
\hline Total population & Water Supply coverage (\%) & Served population & Not served population \\
\hline 120,560 & 51.9 & 62,571 & 57,989 \\
\hline
\end{tabular}

Table 2: Existing water production and consumption of the town

\begin{tabular}{|c|c|c|c|}
\hline \multirow{4}{*}{ 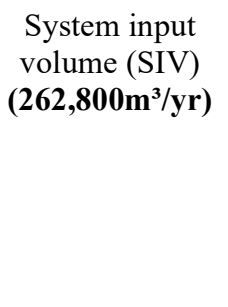 } & \multirow{2}{*}{$\begin{array}{c}\text { Authorized } \\
\text { consumption } \\
\left(\mathbf{1 9 1 , 8 4 4} \mathbf{~ m}^{\mathbf{3}} / \mathbf{y r}\right)\end{array}$} & 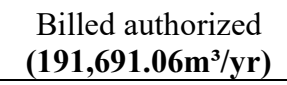 & 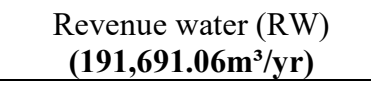 \\
\hline & & $\begin{array}{c}\text { Unbilled authorized } \\
\mathbf{( 1 5 2 . 9 4} \mathbf{~ m 3 / y r )}\end{array}$ & \multirow{3}{*}{$\begin{array}{c}\text { Non-revenue water (NRW) } \\
\left(\mathbf{7 1 , 1 0 8 . 9 4} \mathbf{~ m}^{\mathbf{3}} / \mathbf{y r}\right)\end{array}$} \\
\hline & \multirow{2}{*}{ 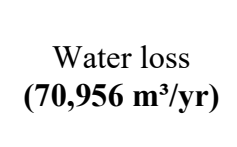 } & 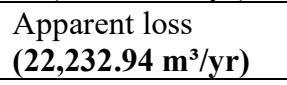 & \\
\hline & & 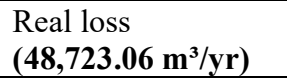 & \\
\hline
\end{tabular}

Real Loss $=48,723.06 \mathrm{~m}^{3} / \mathrm{yr}$ (Major loss $=27,284.88 \mathrm{~m}^{3} / \mathrm{yr}$ and minor loss $=21,438.2 \mathrm{~m}^{3} / \mathrm{yr}$ )

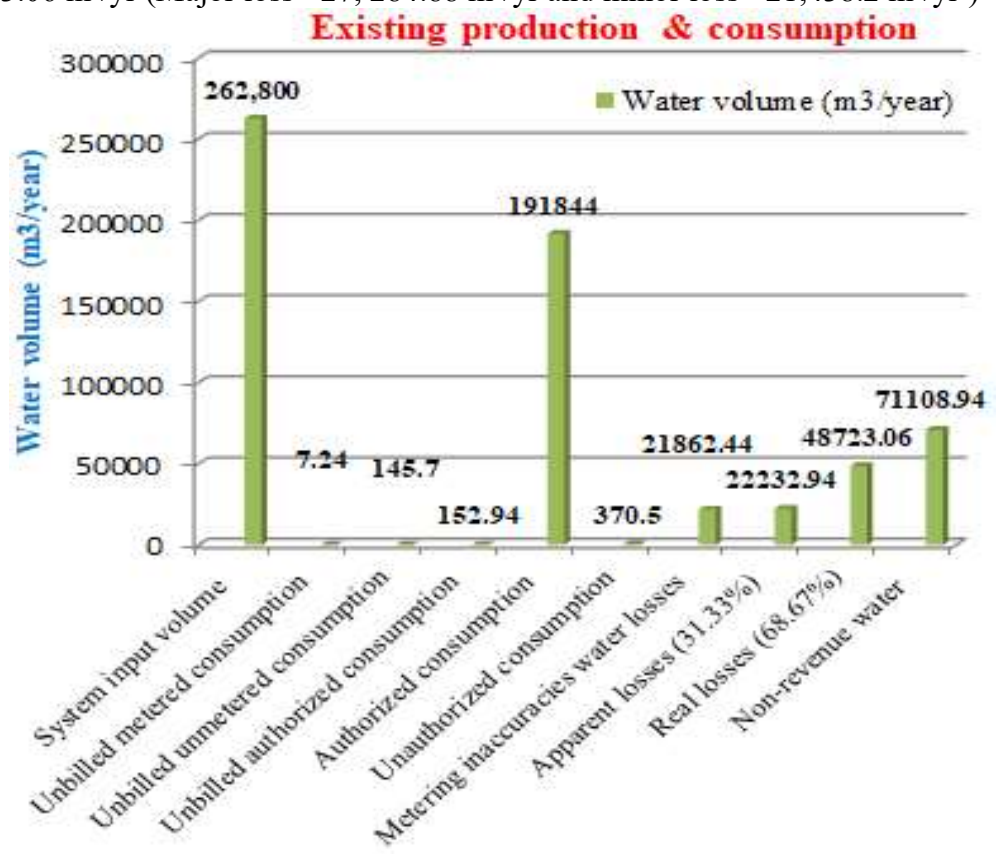

Activities

Figure 2: Production \& consumption situations

As the result from the study shows, about $27 \%$ of the system input volume was loss in the water supply system. From the total loss of water, much of water $(68.67 \%)$ loss was due to system failure. This includes some unauthorized losses and water losses due to metering inaccuracies and the volume of water that was consumed but not paid. 
From the total system input volume (i.e. $\left.262,800 \mathrm{~m}^{3} / \mathrm{yr}\right), 71,108.94 \mathrm{~m}^{3} / \mathrm{yr}\left(194.81 \mathrm{~m}^{3} /\right.$ day $)$ was non-revenue water $(\mathrm{NRW})$ and the remaining $191,691.06 \mathrm{~m}^{3} / \mathrm{yr}\left(525.18 \mathrm{~m}^{3} /\right.$ day $)$ was revenue water $(\mathrm{RW})$.

\section{Water source and accessibility}

Out of the total interviewed sampled HHs, $71.3 \%$ connected to existing water supply system and remaining $28.7 \%$ of sample HHs not connected (Table 3). Around $48 \%$ of the HHs gets their primary water from connections, $22.7 \%$ from public tap, and the remaining $29.3 \%$ get it from vendors and unprotected springs. Regarding to quality, $68.7 \%$ of HHs primary water source was satisfactory in quality and the remaining $31.3 \%$ of the HHs use the primary water with unsatisfactory quality. Around $74 \%$ of sampled $\mathrm{HHs}$ was below the basic access according to the WHO, i.e. $201 / \mathrm{c} / \mathrm{d}$ within $30 \mathrm{~min}$ round trip. Approximately $1 \%$ of the sample respondents travel $>0.5 \mathrm{~km}$ distance to fetch their primary water and majority of the HHs travel a short distance, i.e. $<0.2 \mathrm{~km}$ to fetch their primary water sources; similarly, the majority of the respondents (51\%) spent $>5-30$ min to collect drinking water, $45 \%$ of them $<5 \mathrm{~min}$; the remaining $4 \%$ spent $>30$ min to collect their primary water.

Table 3: Existing water supply status

\begin{tabular}{|c|c|c|}
\hline Items & Descriptions & Percentage $(\%)$ \\
\hline \multirow{2}{*}{ Connection status } & Connected & 71.3 \\
\hline & Not connected & 28.7 \\
\hline \multicolumn{2}{|l|}{ Total (\%) } & 100 \\
\hline \multirow{6}{*}{ Primary sources } & House Connection & 6 \\
\hline & Own Yard Connection & 38 \\
\hline & Shared Yard Connection & 4 \\
\hline & Public Tap & 22.7 \\
\hline & Other (Vendor) & 25.3 \\
\hline & Other(U. Spring) & 4 \\
\hline \multicolumn{2}{|l|}{ Total (\%) } & 100 \\
\hline \multirow{2}{*}{ Quality of Water } & Satisfactory & 68.7 \\
\hline & Unsatisfactory & 31.3 \\
\hline Total (\%) & & 100 \\
\hline \multirow{3}{*}{ Average consumption (L/capita/day) } & $>20$ & 5 \\
\hline & $15-20$ & 21 \\
\hline & $<15$ & 74 \\
\hline \multicolumn{2}{|l|}{ Total (\%) } & 100 \\
\hline \multirow{4}{*}{ Distance from source $(\mathrm{m})$} & $<50$ & 44 \\
\hline & $50-200$ & 49 \\
\hline & $200-500$ & 6 \\
\hline & $>500$ & 1 \\
\hline \multicolumn{2}{|l|}{ Total (\%) } & 100 \\
\hline \multirow{3}{*}{ Average time spent (min) } & $<5$ & 45 \\
\hline & $5-30$ & 51 \\
\hline & $>30$ & 4 \\
\hline \multicolumn{2}{|l|}{ Total (\%) } & 100 \\
\hline \multirow{2}{*}{ HHs using alternative water } & Yes & 88.7 \\
\hline & No & 11.3 \\
\hline Total (\%) & & 100 \\
\hline \multirow{5}{*}{ Alternative source types } & Unprotected spring & 15 \\
\hline & Hand dug well & 37.6 \\
\hline & Public tap & 21.8 \\
\hline & Vendors & 17.3 \\
\hline & River & 8.3 \\
\hline Total (\%) & & 100 \\
\hline \multirow{5}{*}{ Collector from alternative source } & Women & 30.1 \\
\hline & Girls & 36.8 \\
\hline & Boys & 14.3 \\
\hline & Men & 7.5 \\
\hline & All & 11.3 \\
\hline \multicolumn{2}{|l|}{ Total (\%) } & 100 \\
\hline
\end{tabular}


Majority of the sample HHs $(88.7 \%)$ use alternative water sources during the interruption of their primary water sources and, the remaining $11.3 \%$ of HHs do not use any other alternative sources. Majority of the HHs $(52.6 \%)$ use hand- dug wells and unprotected springs for their alternative water sources, $21.8 \%$ from public taps and the remaining $25.6 \%$ of $\mathrm{HHs}$ use rivers and vendors as their alternative water sources. Most often (i.e. $36.8 \%$ of the cases) girls collect water from the alternative water sources (Table 3).

\section{Population and Water Demand Projections}

Depending on the main factors, living standards of the town and currently existing conditions, the design period selected in this case was $20 \mathrm{yr}$.

According to Central Statistical Authority (CSA, 2007) the population of the Areka town was 31,408. CSA method was used to forecast the future population of the town.

Table 4: Annual population growth rate (the medium variant growth rate)

\begin{tabular}{|l|l|l|l|l|l|l|l|}
\hline Year & $\mathbf{1 9 9 5 - 2 0 0 0}$ & $\mathbf{2 0 0 1 - 0 5}$ & $\mathbf{2 0 0 6 - 1 0}$ & $\mathbf{2 0 1 1 - 1 5}$ & $\mathbf{2 0 1 6 - 2 0}$ & $\mathbf{2 0 2 1 - 2 5}$ & $\mathbf{2 0 2 6 - 3 0}$ \\
\hline Growth rate (\%) & 5.3 & 4.8 & 4.6 & 4.3 & 4.1 & 3.9 & 3.7 \\
\hline
\end{tabular}

(CSA, 1994)

To find the annual growth rate beyond the 2030, simple linear extrapolation technique was applied as it showed in the fig. (3); accordingly, the expected annual growth rate for $2031-2035$ is 3.5\% and from 2036-2040 is $3.3 \%$.

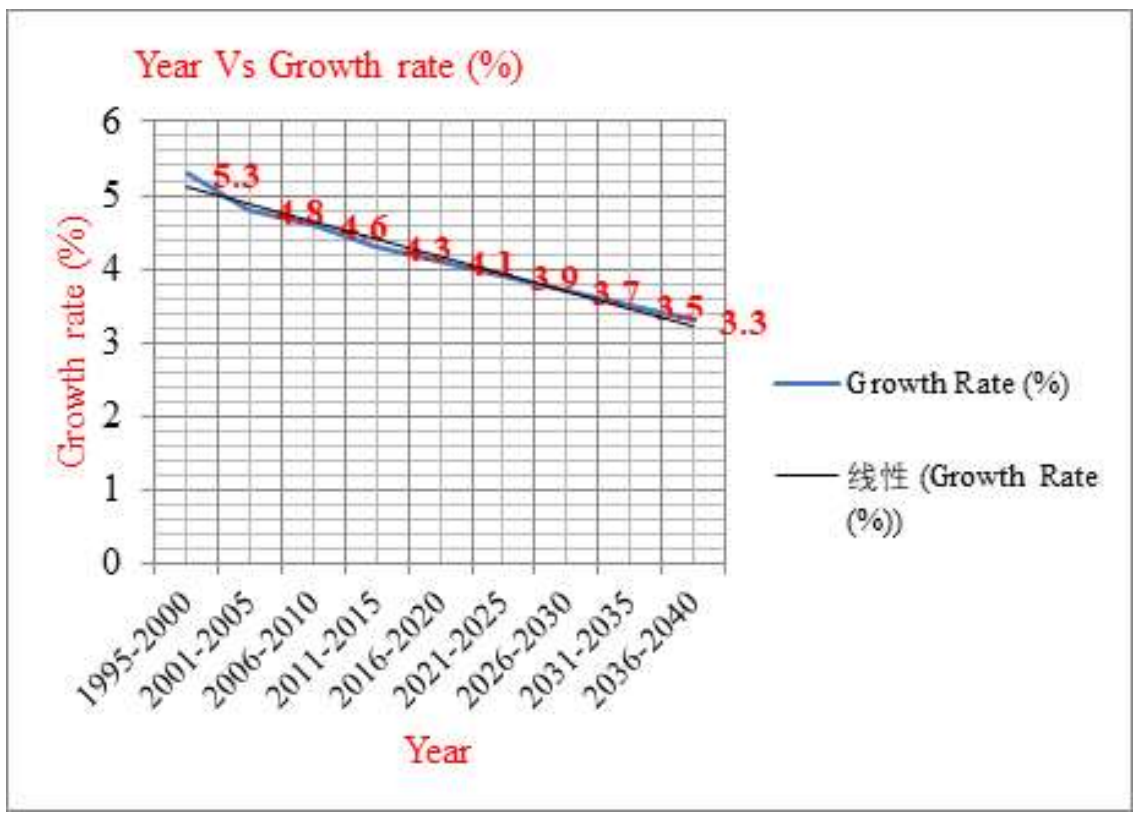

Figure 3: Linear extrapolation of annual growth rate

Table 5: Projected population percentage distribution by each mode of service

\begin{tabular}{|l|l|l|l|l|l|}
\hline \multirow{2}{*}{ Mode of Services } & \multicolumn{4}{|c|}{ Year } \\
\cline { 2 - 6 } & $\mathbf{2 0 2 0}$ & $\mathbf{2 0 2 5}$ & $\mathbf{2 0 3 0}$ & $\mathbf{2 0 3 5}$ & \multicolumn{2}{|c|}{$\mathbf{2 0 4 0}$} \\
\hline House Connection (HC) & $4.1 \%$ & $5.0 \%$ & $7.0 \%$ & $8.2 \%$ & $9.0 \%$ \\
\hline Own Yard Connection (OYC) & $34.8 \%$ & $36.0 \%$ & $38.9 \%$ & $43.0 \%$ & $47.3 \%$ \\
\hline Shared Yard Connection (SYC) & $17.6 \%$ & $21.0 \%$ & $23.8 \%$ & $26.8 \%$ & $30.1 \%$ \\
\hline Public Tap (PT) & $43.5 \%$ & $38.0 \%$ & $30.3 \%$ & $22.0 \%$ & $13.6 \%$ \\
\hline
\end{tabular}

Table 6: Projected average domestic per capita water demand for each mode of services

\begin{tabular}{|l|c|c|c|c|c|}
\hline \multirow{2}{*}{ Mode of Services } & \multicolumn{5}{|c|}{ Year } \\
\cline { 2 - 6 } & $\mathbf{2 0 2 0}$ & $\mathbf{2 0 2 5}$ & $\mathbf{2 0 3 0}$ & $\mathbf{2 0 3 5}$ & $\mathbf{2 0 4 0}$ \\
\hline House Connection (HC) & $501 / \mathrm{c} / \mathrm{d}$ & $601 / \mathrm{c} / \mathrm{d}$ & $701 / \mathrm{c} / \mathrm{d}$ & $801 / \mathrm{c} / \mathrm{d}$ & $901 / \mathrm{c} / \mathrm{d}$ \\
\hline Own Yard Connection (OYC) & $251 / \mathrm{c} / \mathrm{d}$ & $27.5 \mathrm{l} / \mathrm{c} / \mathrm{d}$ & $301 / \mathrm{c} / \mathrm{d}$ & $32.5 \mathrm{l} / \mathrm{c} / \mathrm{d}$ & $351 / \mathrm{c} / \mathrm{d}$ \\
\hline Shared Yard Connection (SYC) & $301 / \mathrm{c} / \mathrm{d}$ & $35 \mathrm{l} / \mathrm{c} / \mathrm{d}$ & $401 / \mathrm{c} / \mathrm{d}$ & $45 \mathrm{l} / \mathrm{c} / \mathrm{d}$ & $501 / \mathrm{c} / \mathrm{d}$ \\
\hline Public Tap (PT) & $201 / \mathrm{c} / \mathrm{d}$ & $22.5 \mathrm{l} / \mathrm{c} / \mathrm{d}$ & $25 \mathrm{l} / \mathrm{c} / \mathrm{d}$ & $27.5 \mathrm{l} / \mathrm{c} / \mathrm{d}$ & $301 / \mathrm{c} / \mathrm{d}$ \\
\hline
\end{tabular}

Depending on the given conditions of the town, its climatic factor (C.F.) is 0.9 and Socio- economic factor (S.F.) is 1.00 (ATWSSE, 2010). According to the design report water supply system of the town, non-domestic 
water demand was considered as $35 \%$ of the total adjusted domestic water demand of the town. Since the projected population of the town above 50,000, the maximum day factor (MDF) was taken as 1.2 and the peak hourly factor (PHF) was taken as 1.7

Table 7: Summary of projected current and future populations and water demands

\begin{tabular}{|l|l|l|c|c|c|c|}
\hline \multirow{2}{*}{ Descriptions } & \multirow{2}{*}{ Unit } & \multicolumn{5}{c|}{ Year } \\
\cline { 3 - 7 } & & $\mathbf{2 0 2 0}$ & $\mathbf{2 0 2 5}$ & $\mathbf{2 0 3 0}$ & $\mathbf{3 0 3 5}$ & $\mathbf{2 0 4 0}$ \\
\hline Population & $\mathrm{No.}$ & 80,645 & 98,009 & 117,927 & 140,480 & 165,681 \\
\hline Domestic water demand & $\mathrm{m}^{3} / \mathrm{d}$ & 1857.3 & 2639.6 & 3733.3 & 5142.0 & 6913.6 \\
\hline Non domestic water demand & $\mathrm{m}^{3} / \mathrm{d}$ & 650.1 & 923.9 & 1306.6 & 1799.7 & 2419.8 \\
\hline \multirow{2}{*}{ Average day demand } & $\mathrm{m}^{3} / \mathrm{d}$ & 3008.9 & 4365.3 & 6199.1 & 8593.8 & 11666.7 \\
\cline { 2 - 7 } & $\mathrm{L} / \mathrm{s}$ & 34.83 & 50.52 & 71.75 & 99.47 & 135.03 \\
\hline \multirow{2}{*}{ Maximum day demand } & $\mathrm{m}^{3 / d}$ & 3610.7 & 5238.4 & 7438.9 & 10312.5 & 14000.1 \\
\cline { 2 - 7 } & $\mathrm{L} / \mathrm{s}$ & 41.79 & 60.63 & 86.10 & 119.36 & 162.04 \\
\hline \multirow{2}{*}{ Peak hourly demand } & $\mathrm{m}^{3} / \mathrm{d}$ & 5115.1 & 7421.0 & 10538.4 & 14609.4 & 19833.4 \\
\cline { 2 - 7 } & $\mathrm{L} / \mathrm{s}$ & 59.2 & 85.9 & 122.0 & 169.1 & 229.6 \\
\hline Total Daily Supply into network & $\mathbf{m}^{3 / d} / \mathbf{3 , 0 0 8 . 9}$ & $\mathbf{4 , 3 6 5 . 3}$ & $\mathbf{6 , 1 9 9 . 1}$ & $\mathbf{8 , 5 9 3 . 8}$ & $\mathbf{1 1 , 6 6 6 . 7}$ \\
\hline Total Annual Supply into network & $\mathrm{m}^{3 / \mathrm{y}}$ & $1,098,249$ & $1,593,334$ & $2,262,665$ & $3,136,732$ & $4,258,351$ \\
\hline Required annual production capacity & $\mathrm{m}^{3} / \mathrm{y}$ & $1,098,249$ & $1,593,334$ & $2,262,665$ & $3,136,732$ & $4,258,351$ \\
\hline
\end{tabular}

\section{Water supply and service level gaps}

As the survey result from the town municipality shows, due to expansion of the town areas and rapid increment of population, the total number of population taken from the town municipality for the current year 2020 was 120,560 . It was greater than the forecasted or expected population for the year 2020 , i.e. 80,645 . But, the supply of water for existing population as indicated in table below was $262,800 \mathrm{~m}^{3} / \mathrm{yr}\left(720 \mathrm{~m}^{3} /\right.$ day or $\left.8.33 \mathrm{~L} / \mathrm{s}\right)$ and it was much less than the required projected supply for the year 2020 , i.e. $10,98249 \mathrm{~m}^{3} / \mathrm{yr}\left(3008.9 \mathrm{~m}^{3} /\right.$ day or $\left.34.82 \mathrm{~L} / \mathrm{s}\right)$. Due to these the shortage of existing supply, for the total existing 120,560 peoples, only 62,691 peoples get their water from existing water supply system of the town (Table 8). This shows the existing water supply coverage was only $51.9 \%$ and the remaining $48.1 \%$ of population do not get water from existing system. Existing per capita water demand for served population was only $11.48 \mathrm{l} / \mathrm{c} / \mathrm{d}$ and it was much less than the required forecasted per capita water demand for the year 2020 i.e. $37.31 \mathrm{l} / \mathrm{c} / \mathrm{d}$

Table 8: Summary of the gaps between existing and required items

\begin{tabular}{|l|l|l|l|}
\hline Items & Existing & Expected & Gaps \\
\hline Total population & 120,560 & 80,645 & 39,915 (excess) \\
\hline Served population & 62,691 & 80,645 & 17,954 \\
\hline Water coverage (\%) & 51.9 & 100 & 48.1 \\
\hline Water production (L/s) & 8.33 & 34.82 & 26.49 \\
\hline Per capita water (L/c/d) & 11.48 & 37.31 & 25.83 \\
\hline
\end{tabular}

\section{CONCLUSIONS}

This study was conducted to assess the existing and to forecast the future water supply and demand status or scenario of the Areka town. The findings lead to the conclusion that there is a huge gap between the water supply and demand of the town. Consequently, in order to satisfy the water demand of the town the following measures should be taken.

* Expansion activities that match with the town development must be carried out to meet the water requirements of the town.

* Additional water sources should be provided to increase total water production capacity of the town

\# The concerned stakeholders should discharge their respective responsibility properly.

\& The town Water Supply and Sewerage Enterprise should devise a mechanism so as to minimize the inequitable distribution of water among the residents of the town.

* Additional study should be conducted to find out other possible causes for water shortage so as to act accordingly.

\footnotetext{
ABBREVIATIONS

AMCOW ............................African Ministers' Council on Water

ATWSSE.........................Areka Town Water Supply and Sewerage Enterprise

C.F.............................. Climatic Factor

CSA ................................... Central Statistical Agency

HC................................House Connection
} 


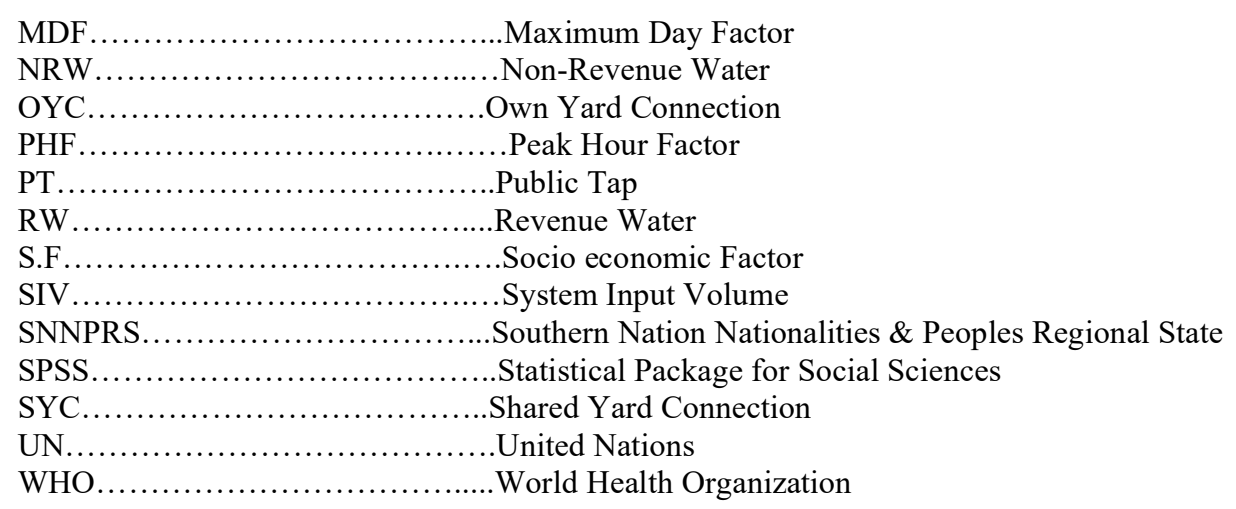

\section{BIBLIOGRAPHY}

Arthur.C. (2014). Urban Water Supply and Sanitation in South East Asia. Philippines, Asia: ASIAN DEVELOPMENT BANK.

ATWSSE. (2010). Areka town Water Supply Project Stage II Feasibility Study and Preliminary Design.

Bogale, B. (2016). Assessment of The Water Distribution Network of Metu Town Water Supply System, Ethiopia.Addis Ababa University.

CSA. (1994). Ethiopian Demographic and Health Survey for SNNPRS. Central Statistical Agency. Addis Ababa: Central Statistical Agency.

CSA. (2007). Population and Housing Cencus of Ethiopia. Central Statistical Authority. Addis Ababa: Central Statistical Authority.

CSA. (2007). The 2007 Population and Housing Census of Ethiopia Natural Statistical Summary Report,. Central Statistics Agency. Addis Ababa: Central Statistics Agency.

Dharmaratna D, Harris E . (2010). Estimating Residential Water Demand Using the Stone-Geary Functional Form: The case of Sri Lanka.

Fink A, Kosecoff J. (1995). How to Conduct Survey: AStep to Step guide . Calif Stage publications.

Fink.A and Kosecoff.J. (1995). How to Conduct Surveys: Astep to Step Guide. Thousand Oaks, Calif Stage Publications.

https://en.wikipedia.org/wiki/Areka. (n.d.). Retrieved from https://en.wikipedia.org/wiki/Areka

https://en.wikipedia.org/wiki/Water_supply_and_sanitation_in_Ethiopia\#Access. (n.d.). Retrieved from https://en.wikipedia.org/wiki/Water_supply and sanitation in Ethiopia\#Access

Makonnen A. (2014). Assessment of Urban Water Supply and Consumption in Asayta Town, Awsiressu Zone, Afar National Regional State, Ethiopia, Thesis, Haramaya University.

Mandefro C, Habtamu K. (2017). Water supply and demand scenario of Dilla Town, Southern Ethiopia.

Rewata J, Sampath R. (2000). Performance Evaluation of Urban Water Supply in Tanzania; The case study of Dar es salaam, Tanzania. Water Resource Development16 (3). London, UK.

Temesgen M., Y. A. (2018). Water Supply Distribution System Design Using in Holeta Town Wolmera Woreda West Shewa Zone of Oromia region, Ethiopia, Arba Minich university. Arbaminch, Ethiopia.

UN. (2012). The Millennium Development Goals Report. New York.

UNICEF. (2011). An AMCOW Country Status Overview; Water Supply and Sanitation in Ethiopia. Addis Ababa: Water and Sanitation Program.

WHO/UNICEF. (2017). Progress on drinking water and sanitation. UNICEF and. 